when, a month before his death, he was made an honorary fellow of Merton.

In zoology, Goodrich's interests were primarily those of a comparative anatomist, in which field he can without exaggeration be claimed as the greatest in the world of his day. There was scarcely a group of the animal kingdom to which he did not devote his attention, or to which he did not make a lasting contribution to knowledge. His first paper was published in 1892, and in the following year he started the remarkable series of papers in which he unravelled the problems of the structure and development of the nephridium and of its distinction from the cœlomoduct. This line of work led him to study the structure and development of most of the forms in which nephridia occur, especially the Annelida and Amphioxus, and to determine the relations of the coelomic cavity, in molluscs, arthropods and the Actinotrocha larva of Phoronis, to mention only a few. He also investigated the systematic position of the Archiannelida in the light of his researches into their structure and development. For the series of text-books on zoology edited by Ray Lankester, Goodrich contributed the section on the holothurioid echinoderms, and the volume on fish. This last work, which was almost entirely based on personal investigation and verification of all facts contained in it, marked an epoch in the study of fish, and through them, of all higher vertebrates. Goodrich clarified the puzzle of the different types of so-called ganoid scales and enabled fossil forms to be compared profitably with living ones. His interest in fossils was indeed no new one, for among his earliest works was a paper on the fossil mammalian jaws from Stonesfield, to which later workers have been able to add very little. $\mathrm{H}_{\Theta}$ investigated the segmentation of the heads of amphibians and selachians, which paralleled for vertebrates the work which he had done in invertebrates on the segmentation of the arthropod head.

Goodrich's "Studies on the Structure and Development of Vertebrates", a large book in which every item was either a result of his own work or was checked by him, is a monument of accuracy, completeness and clear exposition.

His mastery of analytical detail in so many groups enabled Goodrich to make synthetic studies of subjects of general application, such as the relations between metameric segmentation and homology, or the 'faithfulness' of motor nerves to their segmental muscles.

While his predilection for morphological studies may have led some of his contemporaries and juniors to consider him as old-fashioned, Goodrich was always keenly interested in the progress of genetics and experimental zoology, and his acuteness enabled him to cut right through fallacies, some of very old standing, like a knife. He regarded all the changes undergone by an organism during its development as responses to stimuli, some internal (and hereditary) and some external. This point of view not only rendered him appreciative of the results of experimental embryology, but also enabled him to demonstrate the illogicality of the expression 'inheritance of acquired characters' and of Lamarckian hypotheses of the causation of evolution.

From 1915 until 1923 Goodrich was zoological secretary of the Linnean Society of London. In 1921 he began his association with the Quarterly Journal of Microscopical Science, which continued until his death; and all contributors will remember the per- sonal interest which he took in every communication submitted to him, and the helpful suggestions which so frequently increased the value of the paper.

His early training in art served Goodrich in good stead throughout his life. Not only were the illustrations to his papers and his drawings on the blackboard while lecturing really beautiful, but also he had a genuine gift for landscape painting in water colour. He travelled all over the world and always brought back with him a set of pictures, striking alike for their draughtsmanship, composition and colouring. Some of them were shown by him at exhibitions in Bond Street, London.

In 1913 he married Dr. Helen L. M. Pixell, and he collaborated with her in researches on Protozoa.

Goodrich was elected into the fellowship of the Royal Society in 1905 and was awarded a Royal Medal in 1936. He received the Linnean Medal in 1932. In addition to his Oxford degree of D.Sc., he was an honorary LI.D. Edinburgh, honorary D.Se. Dublin, and a foreign or corresponding member of the New York Academy of Sciences, the Swedish Royal Academy of Sciences, the Academy of Sciences of the U.S.S.R., the Belgian Royal Academy, and the Paris Society of Biology.

As a man of science, Goodrich attained the highest standard, but no record of him would be complete without paying tribute to the quiet unassuming charm and loyal friendliness which distinguished him as a man.

G. R. DE BEER.

\section{Academician V. L. Komarov}

Vladimir LeONTIEVICH Komarov died on December 5, 1945, in his seventy-seventh year. He was the doyen of systematic botanists in Russia, expresident of the Academy of Sciences, a deputy of the Supreme Soviet, and holder of the highest Soviet civil award-a Hero of Socialist Labour.

Komarov was born in St. Petersburg in 1869, and was educated at the University there. He was a younger contemporary of Mendeléeff and Timiriazeff. He set out at an early age on a life of exploration, plant collecting, and systematics; and throughout his career these remained his interests in botany. For some years after graduation he collected material ; then followed a series of memoirs on regional floras and studies of separate genera, carried out with a thoroughness and precision which put him in the front rank as an investigator. His travels ranged from Manchuria to Turkistan; and his researches from taxonomy to evolution and anatomy.

Komarov had a forceful, vigorous personality and advanced political opinions; accordingly he was chosen after the October Revolution to be one of the leaders of science in the new Soviet Union. He threw himself with great energy into this task, and he welcomed the increased opportunity for exploration and scientific research. As early as 1914 he had been made a corresponding member of the Academy. In 1919 he was given the chair of botany at Petrograd; and in 1920 he was elected an academician. His outstanding leadership was recognized by his election as vice-president of the Academy in 1930 and president in 1936. During the last ten years Komarov has organized and edited the splendid "Flora of the U.S.S.R.", which has now reached its tenth volume, and which it is planned to complete in twenty-four volumes by 1948 .

During his term as president, Komarov organized the very important war-time activities of the Acad- 
emy. Although his health was failing, he maintained his position as leader of science in the U.S.S.R. up to the time of his retirement, after the celebrations of the Academy in June of last year. These celebrations were an occasion for congratulating Komarov on his service to Soviet science, and for summarizing his life-work. In the Botanical Institute named after him in Leningrad there was an exhibition of maps and photographs illustrating his travels. Despite his illness, Komarov attended the sessions of the Academy, and was admitted to foreign membership of the Linnean Society at one of its meetings. Shortly after these celebrations he retired to a rest home near Moscow.

Even in the last year of his life, Komarov displayed an almost child-like enthusiasm for systematic botany and exploration, and on one occasion crossexamined me in a very impressive way for two hours about the vegetation of eastern Australia.

The honour in which Komarov was held by the Soviet Government is shown by the decree of the Council of Peoples' Commissars to perpetuate his name. The decree includes provision of pensions for his widow and his sister; the issue of Komarov's collected works by the Academy; and four scholarships for post-graduate work.

E. AshBy.

\section{Lady Thiselton-Dyer}

HARRIET, daughter of Sir Joseph Hooker, granddaughter of Sir William Hooker and of Prof. Henslow the Cambridge botanist, wife of Sir William ThiseltonDyer, died, ninety-one years old, in her house near Bere Alston a few days before Christmas Day. She had lived in Kew from childhood to ripe age; her father became assistant-director there under his father the year after she was born, and took over the control ten years later. Sir William Hooker's job had been to turn the private garden of a queen into a garden for the nation and the world; Sir Joseph added nobly to its fame and usefulness, and so did Thiselton-Dyer until he too ceased from his labours. His wife made Kew a very hospitable place; for many years a vacant place was set, and was seldom unoccupied, at every midday meal.

After Dyer's retirement in 1905, his wife and he lived in the Cotswolds until his death in 1928; and then she, widowed and old, went down into Devonshire and made a lovely garden of her own. She had an endless knowledge of plants, and an almost magical skill in gardening. Rare and delicate things, Rosa hemisphorica for one, grew for her without any trouble at all; Calceolaria violacea and $C$. tenella grew rampant over her walls. Fuchsias were one of her latest hobbies; some thirty sorts grew in her garden like weeds, among them the rare $F$. erecta, with its curious upright flowers. She had a Damask rose which she got in her childhood from a very old lady, who had gathered it in Persia in her childhood, more than a hundred and fifty years ago. Once upon a time I happened to find Goodyera repens growing large and plentiful in a Polish forest ; I pressed some between old newspapers and sent them to her as herbarium specimens, but she grew them!

Besides her botany, her Hooker ancestry brought her taste and artistic skill; she was an admirable flower-painter, as Sir William Hooker also had been. The very first time I remember seeing her was in her girlhood, some seventy years ago. She was sitting beside Walter Fitch, who had drawn plants for Sir William for many years; and they were both drawing from herbarium specimens, which had been dipped in boiling water until they opened out, wonderfully, into the natural shape of the flower. She inherited other things besides, such as health, strength, untiring diligence and length of days; she was in her garden until not very long before her death. She kept up a large correspondence, for she was a fluent, easy, intimate letter-writer, after the fashion of a hundred years ago. Her friends loved her and looked up to her; she was très grande dame.

D'Arcy W. Thompson.

\section{Prof. A. E. Taylor, F.B.A.}

THE death of Prof. A. E. Taylor in the late autumn of 1945 at the age of seventy-five deprived these islands of an illustrious humanist and eminent scholar whose spirited vivacity in writing seemed never to tire ; and not these islands only but Europe too, as his honorary membership of the Prussian Academy and of the Accademia dei Lincei partially attested before the War put an end, for the time being, to such graceful glimpses of European comity. Add to this Taylor's eminence as a moralist, his considerable success as a constructive metaphysician in early life and his later high reputation as a liberal defender of orthodox Christianity, and it is plain that the range and variety of his talents was altogether amazing. He excelled in conversation; his letters were literature; and he was very kind.

Taylor's main contribution to straight philosophy, his "Elements of Metaphysics" published in 1903 when he was Frothingham professor of philosophy in McGill University, Montreal, is remarkable for the amount of science, then very new, which he succeeded in incorporating into the somewhat reluctant mould of a metaphysics on F. H. Bradley's linesnon-Euclidean geometry and the labyrinth of the continuum as well as the then more usual excursions into evolution, biology and psychology. This seientific interest, which included proficiency in as well as zest for symbolic methods, remained with Taylor to the end, but found relatively little direct expression except for editing De Morgan's "Formal Logic" in the thirty-five years or thereby during which he taught moral philosophy in Scotland, first at St. Andrews and later at Edinburgh. Then his ruling passion became Platonism and, through Platonism, medievalism, modern ethics and contemporary Christian theology. Burnet's company at St. Andrews had something to do with the Platonism; and Stout, another eminent colleague there, said he found Taylor "ripe for revolt" against the presuppositions of the Common room at Merton (of which College Taylor had been, as Bradley still was, a fellow). In matters of religion no special explanation was needed. The son of a Wesleyan minister, Taylor was always devout, although in Canada he had had a free-thinking phase.

As a Platonist, moralist and theologian, Taylor was especially anxious to maintain that there were great and genuine speculative questions which were extra-scientific in the sense that no answer to them could be 'verified' even 'weakly' by sensory observa. tion. This involved a certain antagonism, very freely expressed, to what he took to be the overweening pretensions of certain men of science; and he was prepared to argue, for example, in "Does God Exist ?", a book that came out almost on the day of his death, that there were world-views, not contra-scientific in any way, according to which, for example, the Virgin 